International Journal of Food Science, Nutrition and Dietetics (IJFS)

ISSN 2326-3350

\title{
Evaluation Of Chlorine Efficacy Against Escherichia Coli O157:H7 Survival And Cross-Contamination During Continuous Produces Washing Processwith Water Quality Change
}

CangliangShen*

Research Article

Department of Biology, Food Science Cluster, Western Kentucky University, Bowling Green KY 42101, USA

\section{Abstract}

Chlorine is widely used by fresh-cut produce processors to reduce pathogens and prevent cross-contamination. However, limited information is available on efficacy of chlorine preventing pathogen survival and the cross-contamination during washing of produce in consideration of wash-water quality change.A study of chlorine against Escherichia coli O157:H7 survival and cross-contamination was conducted simulating produce processors' washing process. Spinach was inoculated with E. coli O157:H7 and manually washed with uninoculated iceberg lettuce in water with initial free chlorine (FC) of $40 \mathrm{mg} / \mathrm{L}$. A total of seven cycles of consecutive washing were conducted until FC $\leq 0.5$ $\mathrm{mg} / \mathrm{L}$. After every $1 \mathrm{~min}$ wash, water and produce were collected to enumerate the surviving E. coli O157:H7 and test water qualities. Water qualities were impacted by consecutive washing and significantly affected the survival and transference of E. coli O157:H7. A reduction of 0.7-0.9 log-CFU/g was observed on spinach. The pathogen survived in wash-water $(0.15-13 \mathrm{MPN} / \mathrm{ml})$ and cross-contaminated onto lettuce (11-33 MPN/g), when wash-water's residual FC was $<4.0-\mathrm{mg} / \mathrm{L}$. Results suggested that wash-water quality change severely limits chlorine inactivation of E. coli $\mathrm{O} 157: \mathrm{H} 7$ on produce and in wash-water, which provides useful information for produce processors to develop washwater sanitizing control systems.

Key Words: Chlorine Water, Escherichia Coli O157:H7, Water Quality, Produce.

\section{*Corresponding Author:}

CangliangShen

Department of Biology, Food Science Cluster, Western Kentucky University, Bowling Green KY 42101, USA.

Tel: 270-745-4440; Fax: 270-745-6856

E-mail: cangliang.shen@wku.edu

Received: February 10,2014

Accepted: February 22, 2014

Published: February 24, 2014

Citation: CangliangShen (2014) Evaluation of Chlorine Efficacy Against Escherichia Coli O157:H7 Survival and Cross-Contamination During Continuous Produces Washing Process with Water Quality Change. Int J Food Sci Nutr Diet. 3(2), 89-93. doi: http://dx.doi.org/10.19070/23263350-1400018

Copyright: CangliangShen ${ }^{\circ}$ 2014. This is an open-access article distributed under the terms of the Creative Commons Attribution License, which permits unrestricted use, distribution and reproduction in any medium, provided the original author and source are credited.

\section{Introduction}

Escherichia coli $\mathrm{O} 157: \mathrm{H} 7$ is an enteric pathogen that can cause life threatening hemorrhagic colitis and hemolytic uremic syndrome [1]. Since 1995, there have been 22 outbreaks of E. coli O157:H7 associated with fresh lettuce or spinach[2]. Washing is one of the most critical processing steps during fresh produce preparation to inactivate pathogens on fresh-cut produces and improvetheir qualityand shelf life[3]. In recent years, hypochlorous acid, referred to as free chlorine (FC), remains the most commonly and effectively used sanitizer for fresh-cut produce processing, although other commercially available chemical sanitizers such as chlorine dioxide, ozone, acidified sodium chlorite, and peroxyacetic acid are allowed to be used during fresh-cut produce washes [4].The ad- vantage of chlorinated water includesstrong bactericidal effects, minimal impact on product quality, and low cost $[3,5,6]$.

In aqueous solution, FCis predominately present as hypochlorous acid $(\mathrm{HOCl})$ near neutral $\mathrm{pH}$, the most effective form of chlorine for disinfection [7]. Thus, sodium hypochlorite solution, at pH 6.5 adjusted by citric acid, is normally used in the fresh-cut produce industry [8]. A previous study conducted by the author showed that free chlorine concentration decreased with increasing amount of organic loads in wash waters [9]. The author also reported thatresidual free chlorine $\geq 0.5 \mathrm{mg} / \mathrm{L}$ with contact time of $30 \mathrm{sec}$ reduced Salmonella spp., E.coli O157:H7 and Non-O157 shiga toxin E. coli populations by more than $4.5 \log \mathrm{CFU} / \mathrm{ml}$ [9]. Chlorinated water typically achieved 1-2 log of microbial reduction on leafy greens $[3,10,11]$. Chlorine solution of $50-200 \mathrm{mg} / \mathrm{L}$ with contact time of 1 to 2 minutesis recommended to sanitize produce surfaces and processing equipmentby US-FDA[4].

During the process of washing fresh produce, the wash water quality deteriorates rapidly as increasing amounts of debris and plant tissue fluids accumulate in the solution. Similar to other oxidant antimicrobial agents, free chlorine is easily consumed by organic matter in the wash solutions, which creates opportunities for pathogens to survive and generate cross-contamination. The FDA recommended thatwater quality parameters including $\mathrm{pH}$, organic load, and turbidity be evaluated to assure that the wash water disinfection is effective in reducingthe potential of crosscontamination between wash water and produce [11]. However, most studies addressing the efficacy of chlorinated water treatment on the microbial pathogen reduction on wash water or produce did not take into account the presence of organic materials expressed as chemical oxygen demand (COD), turbidity, and $\mathrm{pH}$ change [12]. Additionally, most published chlorine decontamination or cross-contamination laboratory studies were conducted by washing produceonly once, thus constituting a "one-time-event" 
experiment [13]. Therefore, this study aimed to evaluate the efficacy of chlorine against E. coli O157:H7 survival and cross-contamination during continuous produce-washing process taken in consideration of wash water quality change.

\section{Materials and Methods}

\section{Bacterial strains and inoculum preparation}

The two-strain mixture of E. coli O157:H7 used in this study included nalidixic acid-resistant derivatives of strains ATCC 43888 and 43889 obtained from Bacteria Strain Collection Center at Western Kentucky University. Nalidixic acid resistant strains were used to allow the selective isolation of the inoculum from natural contaminating flora. Each strain was activated $\left(35^{\circ} \mathrm{C}, 24\right.$ h) separately in $10 \mathrm{ml}$ of tryptic soy broth (TSB; Difco, Becton Dickinson, Sparks, MD) plus $0.1 \mathrm{ml}$ nalidixic acid $(100 \mu \mathrm{g} / \mathrm{ml}$, Sigma-Aldrich, Inc., St. Louis, MO), andsubcultured $(0.1 \mathrm{ml})$ into the same broth at $35^{\circ} \mathrm{C}$ for another 24 hours. The two strains were then combined and centrifuged (Eppendorf model 5810R, Brinkmann Instruments Inc., Westbury, NY) at 4,629 $\times \mathrm{g}$ for 15 min at $4^{\circ} \mathrm{C}$. The harvested cells were washed with $30 \mathrm{ml}$ of phosphate-buffered saline (PBS, pH 7.4; $0.2 \mathrm{~g}$ of $\mathrm{KH}_{2} \mathrm{PO}_{4}, 1.5 \mathrm{~g}$ of $\mathrm{Na}_{2} \mathrm{HPO}_{4} \cdot 7 \mathrm{H}_{2} \mathrm{O}, 8.0 \mathrm{~g}$ of $\mathrm{NaCl}$, and $0.2 \mathrm{~g}$ of $\mathrm{KCl}$ in 1 liter of distilled water), centrifuged as previously described, and resuspended in $30 \mathrm{ml}$ of fresh PBS. The washed inoculum was serially diluted in PBS to obtain a target inoculation level of $6.0 \log \mathrm{CFU} / \mathrm{g}$ when $5 \mathrm{ml}$ of washed cultures was added to $5 \mathrm{~L}$ fresh sterile PBS.

\section{Produce and spinach inoculation}

Fresh iceberg lettuce (Lactuca sativa L.) and baby spinach (Spinaciaoleracea L.) were obtained from a local fresh produce wholesale establishment and used within 2 hour before the experiment. Iceberg lettuce was manually shredded to $1.5-2.0 \mathrm{~cm}$ strips using a sterile knife about 2 hours prior to the washing.Baby spinach leaves $(300 \mathrm{~g})$ were completely immersed in the prepared inoculum solution and kept under manually constant agitation for 15 minutes. Inoculated spinach leaves were then drained in biosafety hood for 1 hour, and stored at 4oC in $20 \mathrm{~g}$ portions for 24 hour before treatment.

\section{Preparation of chlorine solution and measurement of wash water quality}

Achlorine wash solution with $\sim 40.0 \mathrm{mg} / \mathrm{L}$ free chlorine was prepared by diluting $6 \% \mathrm{NaOCl}$ (Clorox, Oakland, CA) into cold distilled water $\left(5^{\circ} \mathrm{C}\right)$ and adjusted to $\mathrm{pH}$ of 6.8 with citric acid. The FCand total chlorine (TC) concentration of solutions after each washing cycle were measured with a commercial test systemincluding a DPD powder dispenser andchlorine photometer (CP15, HF Scientific Inc., Ft. Myers, FL). Water quality characteristics of wash water, including $\mathrm{pH}$, turbidity, oxidation-reduction potential (ORP), and COD, were determined using a digital $\mathrm{pH}$ meter (Fisher Scientific, Fair Lawn, NY), a portable turbidity meter (2020 WE, Fisher Scientific, Fair Lawn, NY), a digital ORPmeter (HI 98120, Hanna Instruments, Smithfield, RI), and a reactor digestion method (COD2 Mercury-Free COD Reagent, $\mathrm{HACH}$ company, Loveland, CO), respectively.

\section{Produce washing process}

One portion of inoculated spinach leaves $(20 \mathrm{~g})$ was immerged in $20 \mathrm{~L}$ of chlorinated washing solution, immediately followed by one portion of shredded lettuce $(1,000 \mathrm{~g})$. Moderate manual stirring ( $\sim 90 \mathrm{rpm} / \mathrm{min}$ ) was applied to keep lettuce and spinach leaves completely submerged for $1 \mathrm{~min}$. Spinach leaves and washed lettuces $(10 \mathrm{~g})$ were immediately sorted out from the wash container into a filtered stomacher bag. Wash water was immediately sampled into $50-\mathrm{ml}$ centrifuge tubes, neutralized with sodium thiosulfate, and filtered (Whirl-Pak filter bag, Nasco, Modesto, CA) for water quality and microbial analyses. After all samples were taken, the remaining washed lettuce was removed and discarded. A second portion of inoculated spinach and non-inoculated lettuce were washed the same way in the same solution. A total of seven cycles of consecutive washing were conducted until free chlorine depleted $(<0.5 \mathrm{ppm})$. The weight equivalent for lettuce for each washing $(1,000 \mathrm{~g})$ was $5 \%$ of that of the wash solution (20L). At the end of 7 washes, the accumulative produce to water ratio was $35 \%$.

\section{Microbiological analysis of wash water and produces}

After every washing cycle, spinach, lettuce and water samples were collected to conduct microbial analysis. Spinach leaves $(20$ g) were placed in a Whirl-Pak filter bag $(1627 \mathrm{ml}, 19 \times 30 \mathrm{~cm}$, Nasco, Modesto, CA) with $100 \mathrm{ml}$ of TSB and homogenized (Masticator, IUL Instruments, Barcelona, Spain) for 2 minutes. Serial tenfold dilutions of each sample, in PBS, were surface-plated onto tryptic soy agar (Acumedia, Lansing, MI) supplemented with $0.1 \%$ sodium pyruvate (Fisher Scientific, Fair Lawn, NY; TSAP) and sorbitol MacConkey agar (BD, Franklin Lakes, NJ) with $\mathrm{NaL}(100-\mathrm{ppm})$ for enumeration of total bacterial populations and inoculated E. coli $\mathrm{O} 157: \mathrm{H} 7$, respectively. Colonies were counted manually after incubation at $35^{\circ} \mathrm{C}$ for $24 \mathrm{~h}$. Triplicate 10 -g lettuce after each washing cycle was also placed into a WhirlPak filter bag with $90 \mathrm{ml}$ of TSB and homogenized for 2 min. The filtered $20 \mathrm{ml}$-water samples were immediately poured into $50-\mathrm{ml}$ centrifuge tubes with $5 \mathrm{ml}$ of $5 \times \mathrm{TSB}$ plus $0.1 \%$ sodium pyruvate and sodium thiosulfate to dechlorinate residual chlorine. The pathogen survivals in lettuce and wash water were enumerated using a modified MPN method previously described. Briefly, eight aliquots $(5 \mathrm{ml})$ from lettuce or water samples were added into an 8x6 deep-well microplate, 10-fold serial diluted in TSB, covered by a sterile foil paper, and incubated overnight (18-24 h) at $35 \mathrm{oC}$. Turbidity of each well was recorded after incubation, and $3-\mu \mathrm{L}$ of droplets from each well were arrayed onto MacConkey agar with $\mathrm{NaL}(100-\mathrm{ppm})$ and incubated at $37^{\circ} \mathrm{C}$ for $24 \mathrm{~h}$. The characteristic E. coli $\mathrm{O} 157: \mathrm{H} 7$ colonies were also confirmed by a rapid RIMTM latex agglutination assay (Remel Inc., Lenexa, KS). The growth pattern was recorded and calculated using an MPN calculator (VB-6 version).

\section{Statistical analysis}

The experiments were conducted with 4 replications. Water quality data including free chlorine, total chlorine, ORP, $\mathrm{pH}$, turbidity, and COD, and microbiological data (survivors or reductions; converted to $\log \mathrm{CFU} / \mathrm{g}$ ) were analyzed using theOne Way ANOVA in the GLM procedures of SAS (SAS Institute, 2002). Means and 
standard deviations for all data were calculated, and the mean differences were separated with the least significant difference procedure at a significance level of $\alpha=0.05$.

\section{Results and Discussion}

\section{Water quality variance during produce washing}

The initial $\mathrm{pH}$, turbidity and COD of chlorinated water solution was $6.81,0.4 \mathrm{NTU}$, and $265 \mathrm{mg} / 1$, respectively, before introducing shredded iceberg lettuce and spinach (Fig 1). Wash water $\mathrm{pH}$ value decreased to 4.99 and returns to 5.45 by the end of 7 washing cycles (Fig 1). As expected, turbidity and COD value of wash water increased proportionally with increasing amount of fresh produce continuously introduced into wash water. By the end of the washing, the water turbidity reached 48 NTU was accompanied by COD increased to $1356 \mathrm{mg} / 1$ (Fig 1), which agreed with previous studies of Luo (2007) [14] and Luoet al. (2012) [15]. Turbidity indicates the wash water quality is associated with soil, debris, and organic matter. COD is used to indirectly determine organics amounts in wash waters. Both are important indexes for monitoring wash water quality during commercial fresh produce washing process. The increasing of turbidity and COD can be explained by the soil and debris from lettuce and spinach and their exudates entering into wash water.

The initial FC and TC of wash water were 40.6 and $40.4 \mathrm{mg} / 1$, respectively (Fig. 2). As shredded lettuce and spinach leaves were continuously washed in wash waters, the FC and TC concentration decreased significantly, and the final residual FC and TC concentration were 0.5 and $8.2 \mathrm{mg} / \mathrm{L}$, respectively (Fig. 2). The dramatic decrease in FC and TC concentration with an increasing level of turbidity and COD during washing is due to the rapid interaction between chlorine and organic materials in wash water through oxidation, addition, and electrophilic substitution reactions [13]. In this study, it is noticed that the residual TC concentration is significantly higher than its corresponding residual FC after each washing cycle. This difference can be explained that FC refers to the amount of elemental chlorine gas (Cl2), hypochlorous acid and hypochlorite, whereas the TCalso included the concentration of residual $\mathrm{NaOCl}$, chloramines, chloroform, and other chemical forms [16].

Oxidation-reduction potential (ORP), measured in millivolts $(\mathrm{mV})$, is defined as the potential oxidation occurring at the anode and/or potential reduction occurring at the cathode of an electrochemical cell [17]. Many fresh-cut produce processors applied ORP level of their wash water system to determine the antimicrobial potential ability of their wash water. In this study, the ORP variance was also monitored during washing of produce. The initial ORP of chlorinated water was $846 \mathrm{mV}$, and it kept high voltage valuesranging from 846 to $896 \mathrm{mV}$ when the FC decreased from 40 to $9.4 \mathrm{mg} / \mathrm{L}$. The final ORP was still as high as $684 \mathrm{mV}$ even though the FC decreased to below $0.5 \mathrm{mg} / \mathrm{L}$ (Fig. 2). Thus, the ORP value is not a reliable indicator to monitor the FC concentration changes in wash water.

\section{Pathogen survival in wash waters during continues washing}

Survival of E. coli $\mathrm{O} 157: \mathrm{H} 7$ in wash wateris directly related to the amount of residual free chlorine during 7 washing cycles. E. coli O157:H7 cells were not recovered from the wash water when the residual free chlorine was more than $4.56 \mathrm{mg} / \mathrm{L}$ (Table 1), indicating that free chlorine is a strong sanitizing reagent for controlling E. coli $\mathrm{O} 157: \mathrm{H} 7$ in water. In a most recent study, the author reported that E. coli O157:H7, non-O157 STEC, or Salmonella spp. cells did not survive in chlorinated water with residual free chlorine concentrations more than $1.0 \mathrm{mg} / \mathrm{L}$ with animmediate contact time of 5-10 s [9]. Similar studies of Yang et al., (2013) [18], Luoet al. (2011) [19], and others [20, 21] also confirmed a rapid bactericidal effect of free chlorine in washing water. In this study, when the residual free chlorine concentration decreased to below $2.0 \mathrm{mg} / \mathrm{L}$, even the ORP was above $720 \mathrm{mg} / \mathrm{L}$, the pathogen started to survive in wash water, resulting a recovered population ranged from 11.3 to $32.3 \mathrm{MPN} / \mathrm{ml}$ (Table 1). In tomato and some produce processors, the option of maintaining an ORP value of $650 \mathrm{mv}$ instead of measuring free chlorine was widely accepted

Figure 1: Variance of $\mathrm{pH}$, turbidity (NTU) and chemical oxygen demand (COD, $\mathrm{mg} / \mathrm{L})$ in sodium hypochlorite solutions by incremental lettuce washes

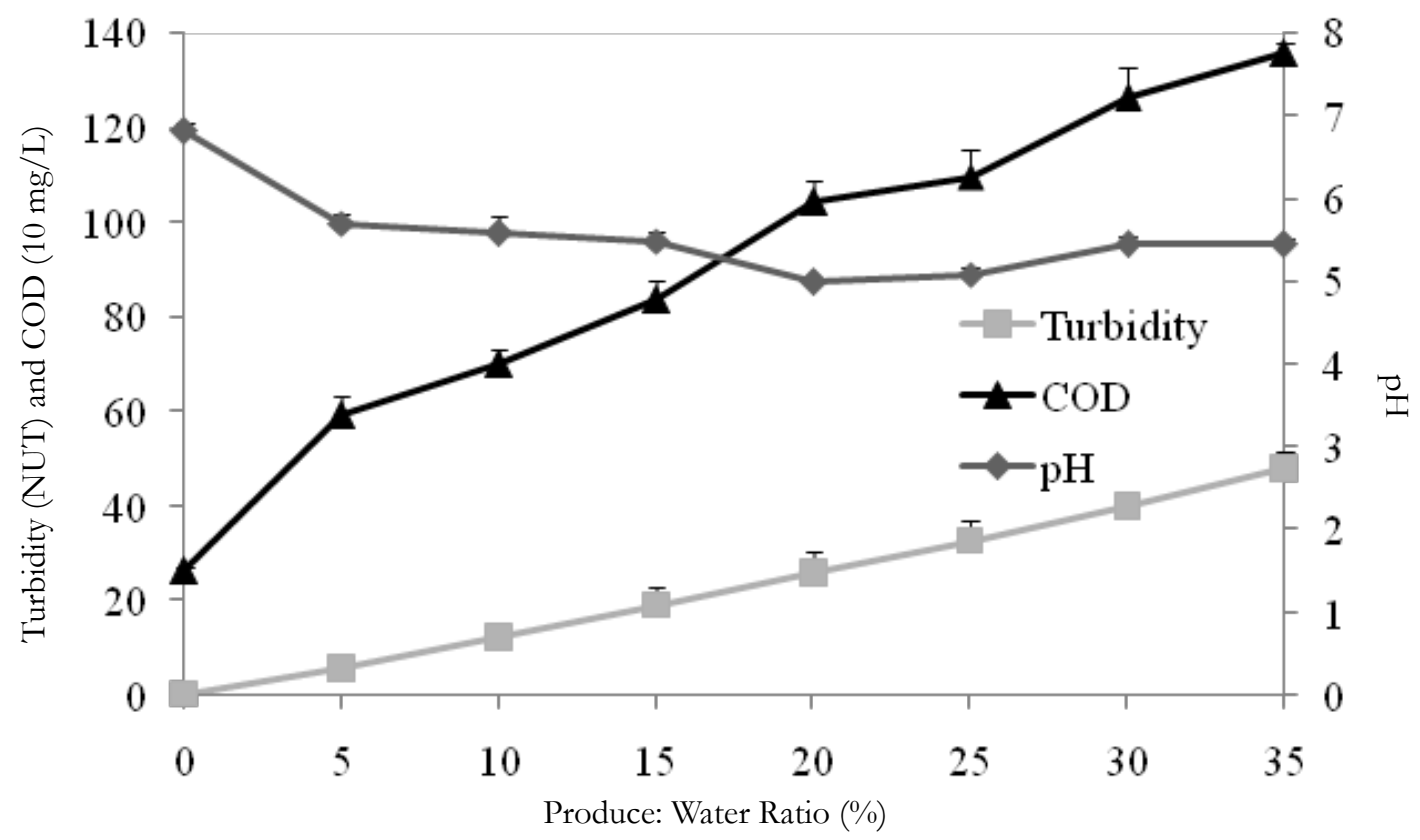


Figure 2: Variance of free, total chlorine concentration $(\mathrm{mg} / \mathrm{L})$ and oxidation-reduction potential (ORP, $+\mathrm{mv})$ in sodium hypochlorite solutions by incremental lettuce washes

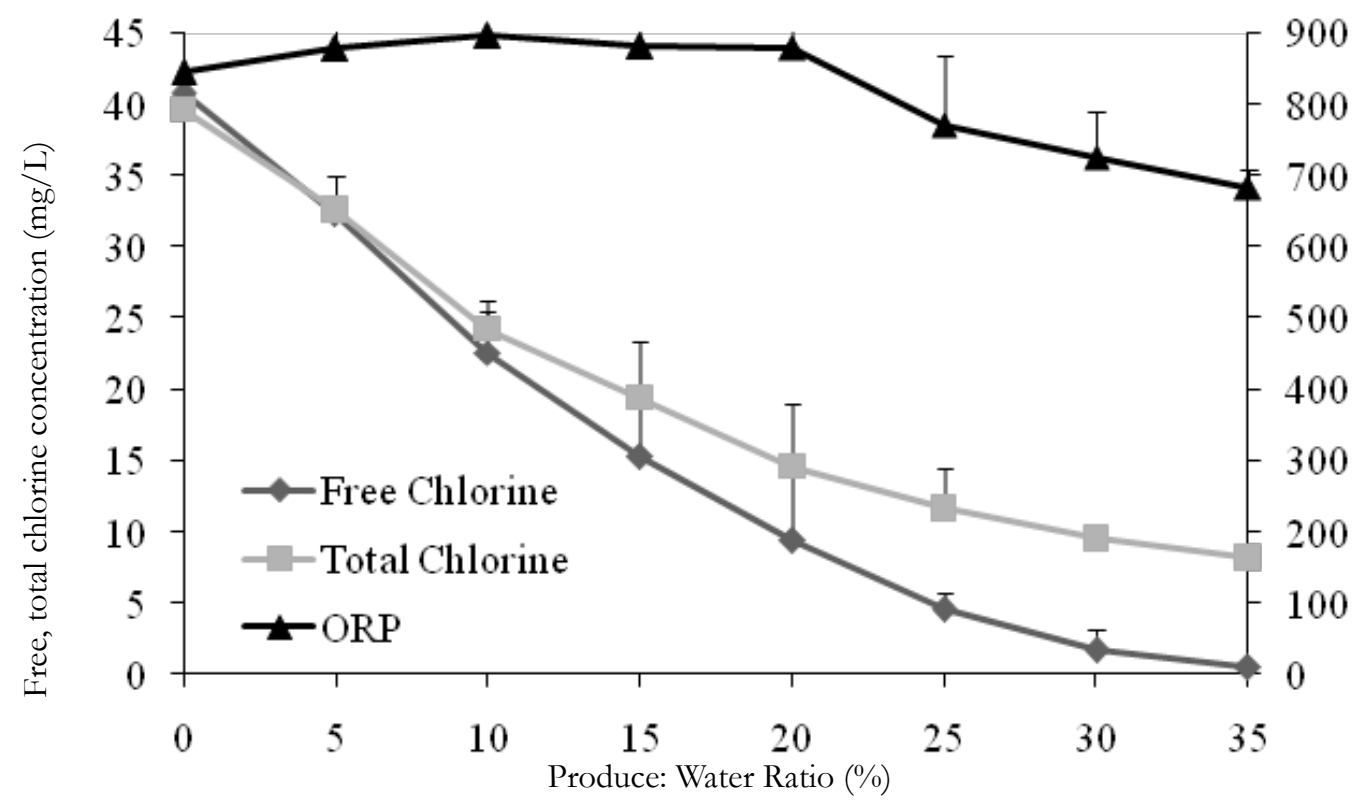

Table 1: Mean ( \pm standard deviation) total bacterial and nalidixic acid-resistant Escherichia coli O157:H7 populations, recovered with tryptic soy agar supplemented with sodium pyruvate (0.1\%) and Sorbitol Mcconkey Agar (Smac) plus nalidixic acid $(100 \mu \mathrm{g} / \mathrm{ml}$, Smac+Nal), respectively, for wash solution, uninoculated lettuce, spinach that were washed in sodium hypochlorite solutions.

\begin{tabular}{|l|l|l|l|l|l|l|}
\hline $\begin{array}{l}\text { Wash cycles } \\
\text { (number) }\end{array}$ & $\begin{array}{l}\text { Produce vs } \\
\text { water ratio } \\
(\%)\end{array}$ & $\begin{array}{l}\text { Residual free } \\
\text { chlorine concen- } \\
\text { tration }(\mathrm{mg} / \mathrm{L})\end{array}$ & $\begin{array}{l}\text { Water solution } \\
(\mathrm{MPN} / \mathrm{ml})\end{array}$ & $\begin{array}{l}\text { Uninocu- } \\
\text { lated lettuce } \\
(\mathrm{MPN} / \mathrm{g})\end{array}$ & $\begin{array}{l}\text { Spinach } \\
(\text { Smac+Nal, log } \\
\text { CFU/g) }\end{array}$ & $\begin{array}{l}\text { Spinach } \\
(\mathrm{TSA}, \log \\
\mathrm{CFU} / \mathrm{g})\end{array}$ \\
\hline 0 & 0 & 40.81 & $\mathrm{ND}$ & $\mathrm{ND}$ & $5.3 \pm 0.1 \mathrm{a}$ & $5.5 \pm 0.2 \mathrm{a}$ \\
\hline 1 & 5 & 32.33 & $\mathrm{ND}$ & $\mathrm{ND}$ & $4.3 \pm 0.3 \mathrm{~b}$ & $5.0 \pm 0.4 \mathrm{~b}$ \\
\hline 2 & 10 & 22.75 & $\mathrm{ND}$ & $\mathrm{ND}$ & $4.4 \pm 0.3 \mathrm{~b}$ & $5.0 \pm 0.2 \mathrm{~b}$ \\
\hline 3 & 15 & 15.32 & $\mathrm{ND}$ & $\mathrm{ND}$ & $4.5 \pm 0.4 \mathrm{~b}$ & $5.1 \pm 0.2 \mathrm{ab}$ \\
\hline 4 & 20 & 9.41 & $\mathrm{ND}$ & $\mathrm{ND}$ & $4.6 \pm 0.3 \mathrm{ab}$ & $5.1 \pm 0.4 \mathrm{ab}$ \\
\hline 5 & 25 & 4.62 & $\mathrm{ND}$ & $0.2 \pm 0.1$ & $4.6 \pm 0.1 \mathrm{~b}$ & $5.1 \pm 0.2 \mathrm{ab}$ \\
\hline 6 & 30 & 1.83 & $11.3 \pm 1.6$ & $13.4 \pm 2.4$ & $4.4 \pm 0.2 \mathrm{~b}$ & $5.0 \pm 0.2 \mathrm{~b}$ \\
\hline 7 & 35 & 0.52 & $32.7 \pm 5.4$ & $11.3 \pm 4.5$ & $4.6 \pm 0.3 \mathrm{ab}$ & $5.1 \pm 0.2 \mathrm{ab}$ \\
\hline
\end{tabular}

a-b: Means with a common letter within a column are not significantly different $(\mathrm{P} \geq 0.05)$.

ND: None detectable below the detection limit of $0.1 \mathrm{MPN} / \mathrm{ml}$ or $0.1 \mathrm{MPN} / \mathrm{g}$.

as a reliable index to monitor wash water sanitizing effects [9]. However, the results of this study, in agreement with other studies[17,22], questioned the reliability of applying ORP index as a proxy for the sanitizing effects of wash water.

\section{E. coli $\mathrm{O} 157: \mathrm{H} 7$ cross-contamination}

The transference of E. coli O157:H7 from contaminated lettuces or baby spinaches to un-contaminated clean produce when free chlorine was depleted in wash waters has been well documented in the studies of Allende et al.(2008) [12], and Luoet al.(2011) [19]; (2012) [15]. In the present study, it is noticeable that when the residual FC concentration was more than $9.4 \mathrm{mg} / \mathrm{L}$, no E. coli O157:H7 cells were detected on fresh clean lettuces (Table 1). As shredded lettuce mixed with inoculated spinach was continuously introduced into chlorinated wash waters, the rapid increase of turbidity and COD caused a significant decline of FC concentration. When the FC concentration decreased to 0.54 to $4.56 \mathrm{mg} / \mathrm{L}$, even though the ORP of water was more than $720 \mathrm{mv}$, the pathogen transferred from contaminated spinaches to fresh uninoculated lettuces, ranging from 0.15 to $13.41 \mathrm{MPN} / \mathrm{g}$ (Table 1). Previous study of Luoet al. 2011[19] found that $10 \mathrm{mg} / \mathrm{L}$ of residual free chlorine was sufficient to prevent cross-contamination of E. coli O157:H7 between contaminated and fresh clean lettuces. The required residual free chlorine concentration to prevent crosscontamination during lettuce washing is higher than that of wash water sanitization. It might be explained by pathogen cells are likely to be embedded in organic matters, and the accumulated organic materials in wash waters may protect them from exposure to sanitizers, allowing them to survive for a long time, and transfer to clean produce [12]. Once clean lettuces were attached with pathogens, a following-up washing will not inactivate the pathogen cells[23]. The findings from this study are important, because the current HACCP plan of chlorinated water sanitization applied by industry produce processers sets the critical control limit of available free chlorine level as $\geq 1 \mathrm{mg} / \mathrm{L}$. Recently, a high amount of free chlorine $(2-5 \mathrm{mg} / \mathrm{L})$ in wash wateris being determined as a critical control limit and is ready to be applied. 


\section{E. coli $\mathbf{O} 157: \mathrm{H7}$ reduction on spinaches}

The overall total average E. coli O157:H7 inoculum level in control (unwashed) spinach leaves was $5.3 \pm 0.1 \log \mathrm{CFU} / \mathrm{g}$. Total bacterial counts on TSA were similar $(\mathrm{P} \geq 0.05)$ to those observed on $\mathrm{TSA}+\mathrm{NaL}$ for all washing cycles, indicating that the majority of colonies found on TSA were inoculated E. coli O157:H7. Washing of inoculated spinach and uninoculated lettuce caused overall pathogen reductions on spinaches by 0.7 to $0.9 \log \mathrm{CFU} / \mathrm{g}$ among 7 washing cycles with FC concentration ranging from 0.5 to $40.8 \mathrm{mg} / \mathrm{L}$. This result agrees with most other authors [24,25], who reported that various chlorine concentrations have no effect on pathogen reductions. For most wash water chemical sanitizers, especially chlorinated water solution, pathogen reductions of 1-2 $\log$ CFU/unit were widely reported by both laboratory scale and pilot plant scale studies $[11,15]$. This finding was slightly lower but close to the other researchers' results, suggesting that pre-harvest decontamination approach is critical in prevention of pathogen contamination during produce processing, and simply relying on post-harvest chlorinated water washing may fail to have any sanitizing effects.

In summary, water quality changedramatically during continuous produce washing process; the accumulated high organic loads severely limit chlorine inactivation of E. coli $\mathrm{O} 157: \mathrm{H} 7$ on produce and in wash-water. The results from this study verified that the pathogen reduction and cross-contamination prevention ability of chlorinated water depends on the available residual free chlorine concentration in wash solutionrather than the amount of chlorine initially dumping into wash water.Therefore, monitoring and maintaining an adequate level of FC during fresh-cut produce washing is extremely important for the control of pathogens in wash water and the prevention of cross-contamination.

\section{References}

[1]. Rasmussen MA, Casey TA (2001) Environmental and food safety aspects of Escherichia coli O157: H7 infections in cattle. Critical Reviews in Microbiology 27: 57-73.

[2]. Cooley M, Carychao D, Crawford-Miksza L, Jay MT, Myers C et al. (2007) Incidence and tracking of Escherichia coli $\mathrm{O} 157: \mathrm{H} 7$ in a major produce production region in California. PLoS One 14: e1159.

[3]. Gil MI, Selma MV, Lopez-Galvez F, Villaescusa R, Allende A (2009) Freshcut produce sanitation and wash water disinfection: problems and solutions. International Journal of Food Microbiology 134: 37-45.

[4]. US-FDA (2009) Chapter 5. Methods to Reduce/Eliminate Pathogens from Produce and Fresh-Cut Produce, Analysis and Evaluation of Preventive Control Measures for the Control and Reduction/Elimination of Microbial Hazards on Fresh and Fresh-Cut Produce. Available at: http://www.fda. gov/Food/ScienceResearch/ResearchAreas/SafePracticesforFoodProcesses/ ucm091363.htm. accessed 2.9.14.

[5]. Gonzalez RJ, Luo Y, Ruiz-Cruz S, Mcevoy JL (2004) Efficacy of sanitizers to inactivate Escherichia coli $\mathrm{O} 157: \mathrm{H} 7$ on fresh-cut carrot shreds under simulated process water conditions. Journal of Food Protection 67: 2375-2380.

[6]. Lopez-Galvez F, Allende A, Selma, MV, Gil MI (2009) Prevention of Escherichia coli cross-contamination by different commercial sanitizers during washing of fresh-cut lettuce. International Journal of Food Microbiology 133: $167-171$

[7]. White GC (2010) White's Handbook of Chlorination and Alternative Disinfectants. In John Wiley, \& Sons (Eds.) 5th Edition, (pp. 1062). New Jersey: Black and Veach Corporation.
[8]. Shen C, Luo Y, Nou X, Bauchan G, Zhou B et al. (2012) Fresh produce washing aid, T-128, enhances inactivation of Salmonella and Pseudomonas biofilms on stainless steel coupons in chlorinated wash solutions. Applied Environmental Microbiology 78: 6789-6798.

[9]. Shen C, Luo Y, Nou X, Wang Q, Millner P (2013) Dynamic effects of free chlorine concentration, organic load, and exposure time on the inactivation of Salmonella, Escherichia coli O157:H7 and Non-O157 Shiga Toxin-Producing E. coli. Journal Food Protection 76: 386-393.

[10]. Parish ME, Beuchat LR, Suslow TV, Harris LJ, Garrett EH et al. (2003) Methods to reduce/eliminate pathogens from produce and fresh-cut produce. Comprehensive Review Food Science Food Safe 2 (Supplement): 161 173.

[11]. US-FDA (2006) Commodity specific food safety guidelines for the lettuce and leaf greens supply chain. Available at: http://www.fda.gov/downloads/ Food/FoodSafety/Product-SpecificInformation/FruitsVegetablesJuices/ GuidanceComplianceRegulatoryInformation/UCM169008.pdfaccessed 2.9.14.

[12]. Allende A, Selma MV, Lopez-Galvez F, Villaescusa R, Gil MI (2008) Impact of wash water quality on sensory and microbial quality, including Escherichia coli cross-contamination, of fresh-cut escarole. Journal of Food Protection12:2514-2518.

[13]. Haute SV, Sampers I, Holvoetk K, Uyttendaele M (2013) Physicochemical quality and chemical safety of chlorine as a reconditioning agent and wash water disinfectant for fresh-cut lettuce washing. Applied Environmental Microbiology 79: 2850-2861.

[14]. Luo Y (2007) Fresh-cut produce wash water reuse affects water quality and packaged product quality and microbial growth in romaine lettuce. Hort Science 42: 1413-1419.

[15]. Luo Y, Nou X, Millner P, Zhou B, Shen C et al. (2012) A pilot plant scale evaluation of a new process aid for enhancing chlorine efficacy against pathogen survival and cross-contamination during produce wash. International Journal of Food Microbiology 158: 133-139.

[16]. Zagory D (2000) Wash water sanitation: How do I compare different systems? 16th Annual Post Harvest Conference \& Trade.Davis Fresh Technologies. Available at: http://postharvest.tfrec.wsu.edu/pages/PC2000Waccessed 2.9.14.

[17]. Suslow T (2011) Establishment of critical operating standards for chlorine dioxide in disinfection of dump tank and flume water for fresh tomatoes. Available at: https://cps.ucdavis.edu/amass/documents/ researchproject $/ 266 / 093010$ final $\% 20$ Suslow $\% 20$ Establishment $\% 20$ of $\% 20$ critical\%20operating\%20standards.pdf accessed 2.9.14.

[18]. Yang Y, Luo Y, Millner P, Shelton D, Nou X (2012) Enhanced chlorine efficacy against bacterial pathogens in wash solution with high organic loads. Journal of Food Processing and Preservation 36: 560-566.

[19]. Luo Y, Nou X, Yang Y, Alegre I, Turner E et al. (2011) Determination of free chlorine concentrations needed to prevent Escherichia coli O157:H7 crosscontamination during fresh-cut produce wash. Journal Food Protection 74: 352-358.

[20]. Carlson S (1991) Fundamentals of water disinfection. Journal of Water Supply: Research and Technology-Aqua 40: 346-356.

[21]. Zhao T, Doyle MP, Zhao P (2001) Chlorine inactivation of Escherichia coli O157:H7 in water. Journal of Food Protection 64: 1607-1609.

[22]. Schneider K, Luo Y, Sargent S, Schneider R (2011) Evaluation and optimization of postharvest intervention strategies for the reduction of bacterial contamination on tomatoes. Available at: Evaluation and optimization of postharvest intervention strategies for the reduction of bacterial contamination on tomatoes; re-accessed on Feb 9th, 2014.

[23]. Lopez-Galvez F, Gil MI, Truchado P, Selma MV, Allende A (2010) Crosscontamination of fresh-cut lettuce after a short-term exposure during prewashing cannot be controlled after subsequent washing with chlorine dioxide or sodium hypochlorite. Food Microbiology 27: 199-204.

[24]. Delaquis PJ, Fukumoto LR, Toivonen PMA, Cliff, MA (2004) Implications of wash water chlorination and temperature for the microbiological and sensory properties of fresh-cut iceberg lettuce. Postharvest Biology and Technology31:81-91.

[25]. Pirovani M, Piagentini A, Guemes D, Silvana A (2004) Reduction of chlorine concentration and microbial load during washing-disinfection of shredded lettuce. International Journal Food Science Technology39: 341-347. 